\title{
BLOCK SLOPE IS THE MAIN DETERMINANT OF BLOCK PHASE PERFORMANCE IN SWIMMING
}

Original Article

Artigo Original

Artículo Original
A INCLINAÇÃO DO BLOCOÉO PRINCIPAL DETERMINANTE DO DESEMPENHO DA FASE DEBLOCO
EMNATAÇÃO

\author{
LA INCLINACIÓN DEL BLOQUEESEL PRINCIPAL DETERMINANTE DEL DESEMPEÑO DE LAFASEDE \\ BLOQUEENNATACIÓN
}

Uğur ÖDEK' ID

(Physical Education Professional)

Feza KORKUSUZ² (iD

(Medical Doctor, Orthopedic Surgeon)

Sadettin KIRAZCI ${ }^{3}$ (ID

(Physical Education Professional)

1. Nevsehir Hacı Bektas Veli University, Physical Education and Sports Department, Nevşehir, Turkey.

2. Hacettepe University Medical Faculty, Department of Sports Medicine, Ankara, Turkey. 3. Middle East Technical University, Physical Education and Sports Department, Ankara, Turkey.

\section{Correspondence:}

Uğur ÖDEK. Nevşehir Hacı Bektaş Veli Üniversitesi Eğitim Fakültesi Beden Eğitimi ve Spor Eğitimi Bölümü 3. Kat oda no: 20450300 Nevşehir, Turkey. ugurodek@nevsehir.edu.tr

\begin{abstract}
Introduction: Swimming starts are an important component for decreasing the total race time, especially in short events. In this phase of swimming, the aim is to increase performance using many different techniques and starting platforms. Objectives: The effects of height and slope of the starting block on kick-start performance were assessed in this study. Methods: Six male competitive swimmers performed 24 kick-starts using four block settings: $65 \mathrm{~cm} \& 75 \mathrm{~cm}$ flat and $65 \mathrm{~cm} \& 75 \mathrm{~cm}$ sloped. Two-dimensional kinetic and three-dimensional kinematic data were analyzed, including average and maximum horizontal/vertical forces and impulses; reaction times; movement and block times; and take-off vertical/horizontal velocities. Two-way within-subject design ANOVAs were implemented to test the effects of block height and slope on the kinetic and kinematic variables. Results: Block slope was the main factor affecting most of the dependent variables. Shorter block and movement times, greater average and maximum vertical forces, vertical impulse, and maximum horizontal force were found for the sloped settings. An inverse relationship was found between block height and 0-5 $\mathrm{m}$ times. Conclusion: Based on the results, blocks with height of $75 \mathrm{~cm}$ and slope of $10^{\circ}$ provided better results in swimmers'performance in the block phase. Level of evidence ll, Therapeutic Studies Investigating the Results of Treatment
\end{abstract}

Keywords: Biomechanical phenomena; Kinetics; Kinematics; Swimming.

\section{RESUMO}

Introdução: As largadas de natação são um componente importante para reduzir o tempo total de competição, especialmente em eventos curtos. Nessa fase da natação, o objetivo é aumentar o desempenho usando várias técnicas e plataformas de largada distintas. Objetivos: Neste estudo, foram avaliados os efeitos da altura e da inclinação da plataforma sobre desempenho da saída kick-start. Métodos: Seis nadadores de competição do sexo masculino realizaram 24 largadas, usando quatro tipos de bloco de partida ( $65 \mathrm{~cm}$ e $75 \mathrm{~cm}$ de altura planos e $65 \mathrm{~cm}$ e $75 \mathrm{~cm}$ com inclinação). Foram analisados dados cinéticos bidimensionais e cinemáticos tridimensionais, incluindo forças e impulsos horizontais/ verticais médios e máximos; tempos de reação, movimento e de bloco; e velocidades vertical/horizontal da decolagem. Empregou-se o método ANOVA bidirecional intraindividuo para analisar os efeitos da altura e da inclinação do bloco sobre as variáveis cinéticas e cinemáticas. Resultados: A inclinação do bloco foi o principal fator que afetou a maioria das variáveis dependentes. Nas plataformas de largada inclinadas, verificou-se que os tempos de bloco e movimento eram mais curtos e as forças verticais médias e máximas, o impulso vertical e a força horizontal máxima foram maiores nas configurações inclinadas. Foi encontrada uma relação inversa entre a altura do bloco e os tempos para as distâncias de 0 a 5 metros. Conclusões: Com base nos resultados, os blocos com $75 \mathrm{~cm}$ de altura e 10 graus de inclinação forneceram melhores resultados de desempenho dos nadadores na fase de bloco. Nível de Evidência ll - Investigação dos resultados do tratamento.

Descritores: Fenômenos biomecânicos; Cinética; Cinemática; Natação.

\section{RESUMEN}

Introducción: Las largadas de natación son un componente importante para reducir el tiempo total de competición, especialmente en eventos cortos. En esta fase de natación, el objetivo es aumentar el desempeño usando varias técnicas y plataformas de largada distintas. Objetivos: En este estudio, fueron evaluados los efectos de la altura y de la inclinación de la plataforma sobre desempeño de la salida kick-start. Métodos: Seis nadadores de competición del sexo masculino realizaron 24 largadas, usando cuatro tipos de bloque de partida $(65 \mathrm{~cm}$ y $75 \mathrm{~cm}$ de altura planos y $65 \mathrm{~cm}$ y $75 \mathrm{~cm}$ con inclinación). Fueron analizados datos cinéticos bidimensionales y cinemáticos tridimensionales, incluyendo fuerzas e impulsos horizontales/verticales promedios y máximos; tiempo de reacción, movimiento y de bloque; y velocidades vertical/horizontal del despegue. Se empleó el método ANOVA bidireccional intraindividuo para analizar los efectos de la altura y de la inclinación del bloque sobre las variables cinéticas y cinemáticas. Resultados: La inclinación del bloque fue el principal factor que afectó a la mayoría de las variables dependientes. En las plataformas de largada inclinadas, se verificó que los tiempos de bloque y movimiento eran 
más cortos y las fuerzas verticales promedio y máximas, el impulso vertical y la fuerza horizontal máxima fueron mayores en las configuraciones inclinadas. Fue encontrada una relación inversa entre la altura del bloque y los tiempos para las distancias de 0 a 5 metros. Conclusiones: Con base en los resultados, los bloques con $75 \mathrm{~cm}$ de altura y 10 grados de inclinación proporcionaron mejores resultados de desempeño de los nadadores en la fase de bloque.

\section{Nivel de Evidencia II; Investigación de los resultados del tratamiento}

\section{Descriptores: Fenómenos biomecánicos; Cinética; Cinemática; Natación}

\section{INTRODUCTION}

Swimming starts are accepted as a critical component of the total race time especially in short events. ${ }^{1,2}$ The start is divided into the block, the flight and the underwater phases that begin with the starting signal, the take-off and entry. ${ }^{3-6}$ The contribution of these phases to overall start performance can be approximated as 11\%, 5\% and 84\%, respectively. ${ }^{5}$ Despite its relatively small contribution, the block phase has a significant effect on the following phases, since the take-off velocity and angle are determined in this phase. ${ }^{4,7}$

In 2008, the Swiss company Omega made a distinctive modification on the blocks and produced a starting block (OSB11) with a footrest. Since 2009, they have been used in nearly all major competitions including, the 2012 and the 2016 Summer Olympics. OSB11's adjustable (in back and forth direction) $30^{\circ}$-sloped and $12 \mathrm{~cm}$-elevated footrest is placed at the back end of the block. ${ }^{8}$ The footrest changed the characteristics of the start technique on a large scale, ${ }^{9-12}$ and consequently, a new starting technique called kick-start was emerged. Research on kick-start demonstrated a significant contribution of the footrest to the overall start performance. ${ }^{9,11,13,14}$ Studies that compared the kick-start and the traditional track-start indicated time improvements in $5 \mathrm{~m}-7.5 \mathrm{~m}, 10 \mathrm{~m}$ and $15 \mathrm{~m}$ distances. ${ }^{14,9,11}$ Shared findings of these studies pointed out an increase in both horizontal and vertical take-off velocities and decrease in movement time. Researchers associated these advancements to factors such as augmented rear leg involvement, the center of mass position and feet placement. $14,9,10$

The effects of block height, block slope and both were investigated in previous studies. ${ }^{15,16-18,19}$ Cornett, White ${ }^{15}$ concluded that there was a non-linear relationship between block height. ${ }^{21,46,76}$ and head velocity and swimmer's head velocity at maximum depth when the preferred start technique was used. Stewart ${ }^{18}$ found the effect of block slope $\left(0,10^{\circ}\right)$ on take-off velocity was non-significant for grab start. Elliot and Sinclair ${ }^{16}$ explored the effects of three block slopes $\left(0,10,15^{\circ}\right)$ and indicated a non-linear relationship regarding horizontal velocity. Stevenson and Morehouse ${ }^{17}$ used blocks that were sloped between $0-30^{\circ}$, and they found that $20^{\circ}$ was the most advantageous slope for a grab start. On the other hand, they did not find a time difference between performances started on the $0^{\circ}$ and $20^{\circ}$ sloped blocks for $22.86 \mathrm{~m}$ (25yards). Gehlsen and Wingfield ${ }^{19}$ indicated significant main effects of block height $(.46, .56, .66, .76 \mathrm{~m})$ and slope $\left(0,10^{\circ}\right)$ for the center of gravity velocity upon the water surface. According to their results, both vertical and resultant velocities were increased due to an increase in block height and slope. Nevertheless, none of these researchers instrumented a starting block with a footrest to measure the effects of different block installations on kick-start performance.

The scope of this study was to explore the effects of height and slope of the starting block with a footrest on swimming start. We hypothesized that block height and slope have effects on block phase of start. Research questions were whether block height and slope affect reaction time $(\mathrm{RT})$, movement time $(\mathrm{MT})$ ), block time $(\mathrm{BT})$, average, maximum horizontal/vertical forces (Ave_H $H_{F}, M a x \_H_{F}$ Ave_V $V_{F} M a x \_V_{F}$ ) and horizontal/vertical impulses $\left(H_{j}, V_{j}\right)$, centre of mass distance to front edge (Dis_CM), angular displacement of centre of mass (Ang_D_CM), and take-off velocity angle (Ang_Vel), take-off horizontal $\left(\mathrm{TO}_{-} \mathrm{H}_{V}\right)$ and vertical velocity $\left(\mathrm{TO}_{-} \mathrm{V}_{\mathrm{v}}\right), 0-5 \mathrm{~m}$ time $(\mathrm{t}-5 \mathrm{~m})$.

\section{METHOD}

\section{Participants}

Six male competitive swimmers whose major strokes are butterfly and freestyle participated (Table 1). All swimmers considered as experienced in sprint events with the achievement of approximately 750 FINA points for $50 \mathrm{~m}$ races. They were informed of the data collection procedures and filled-signed a consent form prior to the study. The consent form was in accordance with the Declaration of Helsinki as amended by the World Medical Association Declaration of Helsinki (World Medical Association, 2013). Ethical Board of Middle East Technical University (28620816/88-139) approved the study.

\section{Data collection and analysis procedure}

Participants completed their usual warm-up (approx. 30min) for $50 \mathrm{~m}$ freestyle or butterfly races, and they experienced the block settings by five to ten repetitions for the familiarization before the trials. Three starts from a block with a $65 \mathrm{~cm}$ height, and a flat surface $(65 \mathrm{~cm}$ _flat) were performed initially. The swimmers respectively performed the same number of starts from blocks with a $75 \mathrm{~cm}$ height and a flat surface $\left(75 \mathrm{~cm} \_\right.$flat), a $65 \mathrm{~cm}$ height and a $10^{\circ}$ sloped surface $(65 \mathrm{~cm}$ sloped), a $75 \mathrm{~cm}$ height and $10^{\circ}$ sloped surface $(75 \mathrm{~cm}$ _sloped) on each other day. Undulatory movements were not allowed for the first $5 \mathrm{~m}$. Five-minute breaks were given to avoid muscle fatigue after each start. Swimmers used preferred feet placement and body position on the blocks. Analyses were carried out of the best $0-5 \mathrm{~m}$ timed performances of each block setting.

RT was calculated as the time interval between the starting signal and the first impulse generated by the swimmer. MT was calculated as the time interval between the first impulse after the starting signal and the last impulse before the take-off. Sum of RT and MT was calculated as BT. Ave_H $H_{F}$ and Ave_ $V_{F}$ were the averages, Max_H $H_{F}$ and Max_ $V_{F}$ were the maximum horizontal/vertical force magnitudes (calculated as ground reaction force) generated by the swimmer during movement. $\mathrm{H}_{\text {, }}$ and $\checkmark$, were calculated using force ${ }^{*}$ time formula.

Table 1. Descriptive Statistics and 0-5m Times of Participants.

\begin{tabular}{c|c|c|c|c|c|c|c|c|c}
\hline & & & & $\begin{array}{c}\text { Best Time } \\
(\mathbf{s})\end{array}$ & \multicolumn{4}{|c|}{$\begin{array}{c}\text { 0-5m Times of } \\
\text { Selected Trials (s) }\end{array}$} \\
\hline Participants & $\begin{array}{c}\text { Age } \\
\text { (year) }\end{array}$ & $\begin{array}{c}\text { B. Weight } \\
(\mathbf{k g})\end{array}$ & $\begin{array}{c}\text { Height } \\
(\mathbf{c m})\end{array}$ & B.fly & F.style & $\begin{array}{c}\text { 65cm } \\
\text { Flat }\end{array}$ & $\begin{array}{c}75 \mathrm{~cm} \\
\text { Flat }\end{array}$ & $\begin{array}{c}\text { 65cm } \\
\text { Sloped }\end{array}$ & $\begin{array}{c}\text { 75cm } \\
\text { Sloped }\end{array}$ \\
\hline P1 & 16.9 & 84.6 & 182.6 & 24.6 & 23.1 & 1.91 & 1.89 & 1.9 & 1.89 \\
\hline P2 & 18.3 & 86.3 & 187.6 & 25.1 & 23.6 & 1.92 & 1.9 & 1.93 & 1.89 \\
\hline P3 & 17.7 & 81.2 & 178.3 & 26.2 & 23.1 & 2.03 & 1.99 & 2.01 & 2 \\
\hline P4 & 18.7 & 85.4 & 179.5 & 24.1 & 22.9 & 2.03 & 1.98 & 2.01 & 1.99 \\
\hline P5 & 16.2 & 78.3 & 176.4 & 24.2 & 23.2 & 2.03 & 2.02 & 2.02 & 2.01 \\
\hline P6 & 19.4 & 80.1 & 180.6 & 24.3 & 23.3 & 2.1 & 2.02 & 2.02 & 2 \\
\hline Mean & 17.9 & 82.7 & 180.8 & 24.8 & 23.2 & & & & \\
\hline SD & 1.2 & 3.2 & 3.9 & 0.8 & 0.2 & & & & \\
\hline
\end{tabular}


Modified weighted segmental model by de Leva ${ }^{20}$ was used to calculate the Centre of Mass (CM) of the swimmers. Dis_CM was the horizontal distance between swimmer's CM and the imaginary perpendicular line originated from starting block's front edge. Dis_CM was measured when the swimmer was at the set position. Ang_D_CM was the total angular change of CM during movement in the sagittal plane. Ang_Vel was the theta angle of the resultant velocity vector at take-off. $\mathrm{TO}_{-} \mathrm{H}_{V}$ and TO_ $\mathrm{V}_{V}$ were the swimmers' $\mathrm{CM}$ vertical and horizontal velocity at take-off, which was calculated using change in the position of CM over the time interval between the take-off and the previous three image frames. Variables related to kinematics were calculated via the 3D motion analysis software (SkillSpector@, Video4Coach, Denmark). 0-5m times were measured as the time taken from the starting signal for the top of the head to touch a line drawn on the image recorded by the video camera

\section{Kinematic data collection and analysis}

Eighteen pre-determined anatomical landmarks (Figure 1) were marked using $2 \mathrm{~cm}$ diameter circular black stickers. Four high-speed cameras (PlayStation ${ }^{\text {TM }}$ Eye, Japan) were connected to a high-performance notebook (Asus, G53SX, Taiwan) to capture the block phase of the start. The camera setup was prepared as in the study of Taladriz, de la Fuente-Caynzos ${ }^{21}$ with distance modifications. The first camera was placed diagonally $2.5 \mathrm{~m}$ away from the left rear edge of the starting block, and the second camera was placed diagonally $2.5 \mathrm{~m}$ away from the left front edge of the starting block. The other two cameras were placed on the opposite side of the starting block with the same angulations and distances (Figure 2). Another camera was placed perpendicular to the participant's plane of motion to measure the $0-5 \mathrm{~m}$ time. Cameras were synchronized, and video clips were recorded at 60fps via the iPi Recorder Software@ (iPi Soft, LLC, Russia).

Digitized points were used to build a 3D human models (Figure 3). For the post-processing, $60 \mathrm{~Hz}$ data was transformed to $100 \mathrm{~Hz}$ using cubic spline interpolation to match the kinematic and kinetic data in the frequency domain as seen in the study of O'Connor, Thorpe, O'Malley, and Vaughan (2007).

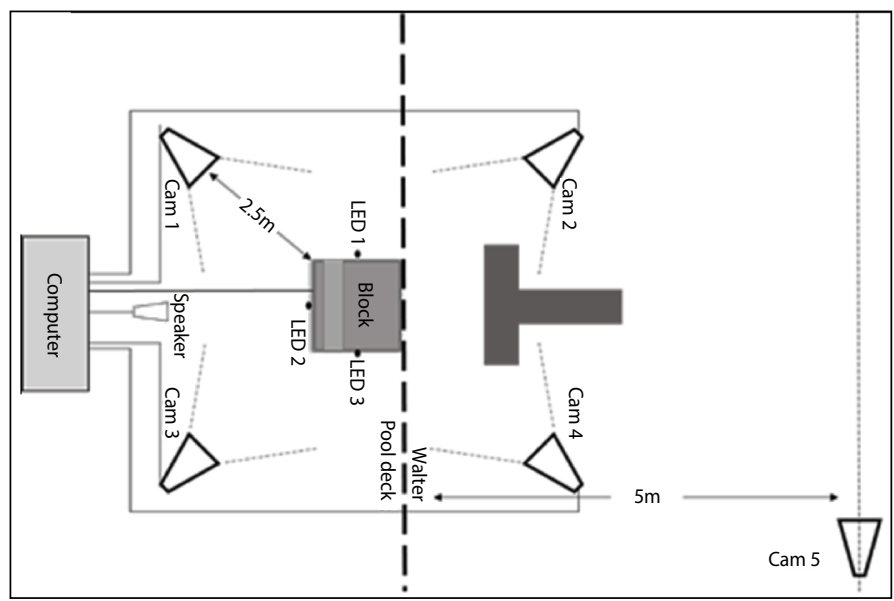

Figure 2. Measurement Setup.

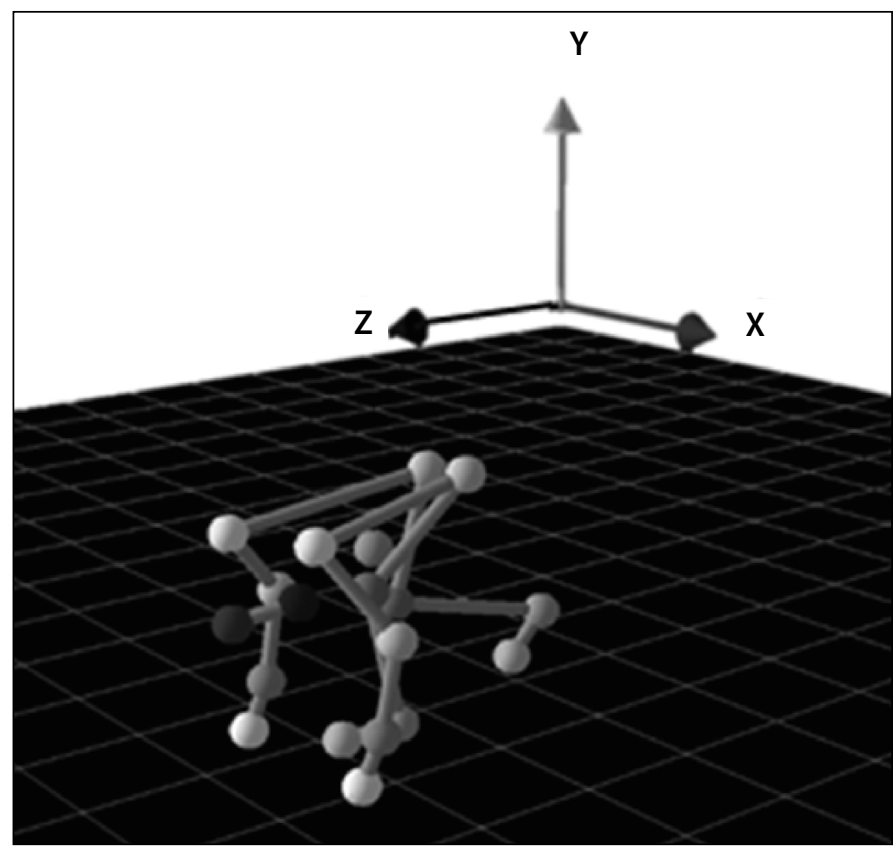

Figure 3. Three-Dimensional Stick Figure of a Swimmer.

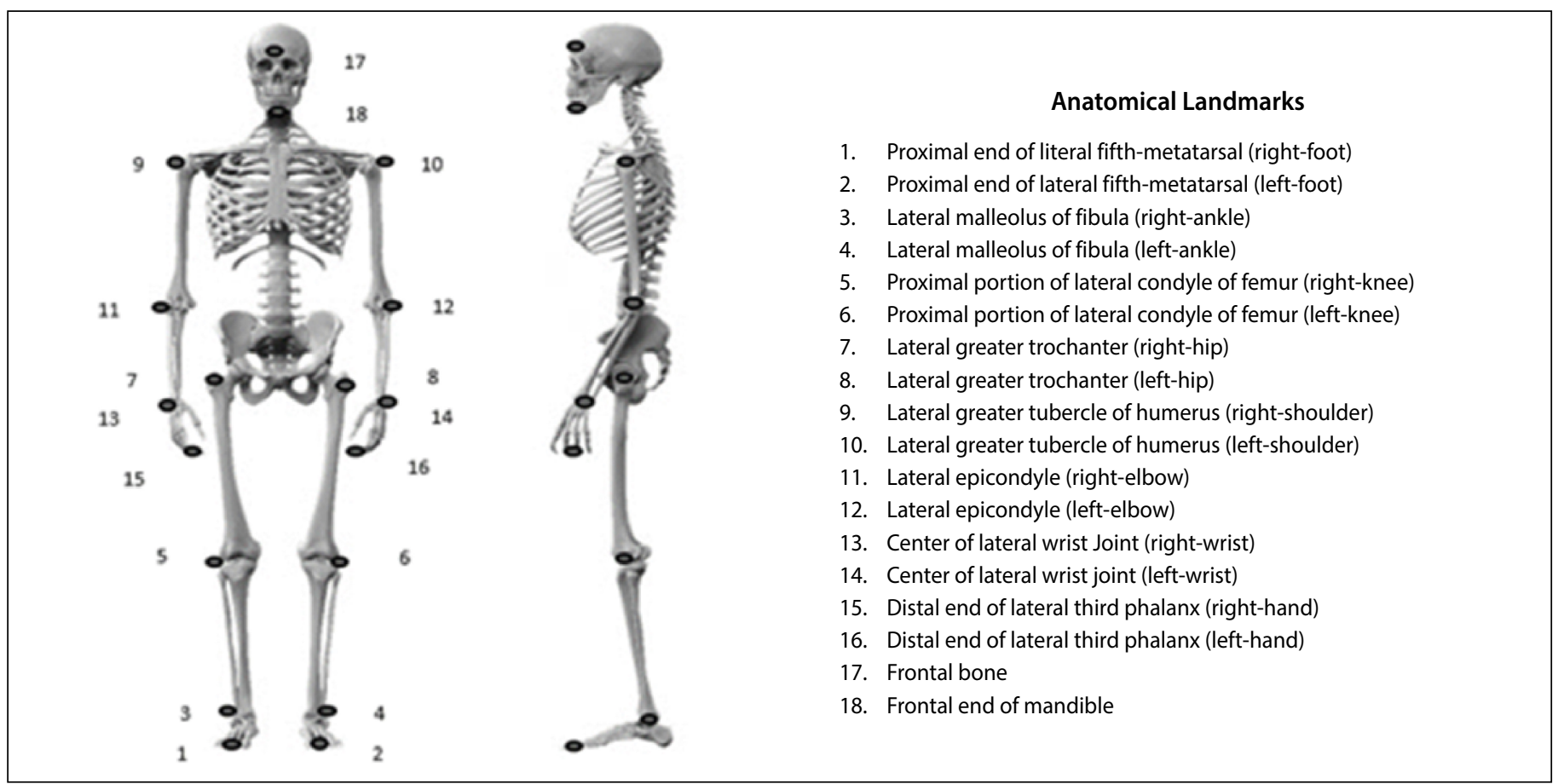

Figure 1. Marker Locations. 


\section{Kinetic data collection and analysis}

An OSB11 replica equipped with four load cells (3 for the vertical axis, 1 for the horizontal axis; NBC Elettronica, Spain) used for all measurements (Figure 4). Ground reaction force (GRF) data were collected at $1000 \mathrm{~Hz}$ using a NI WLS/ENET-9163 (National Instruments, ABD) wireless carrier with an embedded NI 9237 (National Instruments, ABD) series measurement module. A virtual instrument created in LabVIEW@ (Ver. 2012, National Instruments, ABD) software was used for data accusation and logging procedures. Each swimmer's vertical and horizontal GRFs were normalized to their body weight before analyses and resampled into $100 \mathrm{~Hz}$ using the same cubic spline interpolation method. The accuracy of the platform was tested with both static and dynamic approaches. For the static vertical test, after the force readings were zeroed, 50-100-150$200 \mathrm{~kg}$ International Weightlifting Federation certified lifting discs (Eleiko, Sweden) were placed on the platform while the platform's surface was in parallel to the horizontal plane. In order to measure horizontal force, the same discs were hung from the rear end of the platform surface with a $1.5 \mathrm{~kg}$ steel apparatus while the platform's surface was in parallel to the vertical plane. Loadings were done for 15 times for each weight and each axis. For the dynamic test, an 'S' type load cell (NBC Elettronica, Spain) that connected to DAQ card was pulled with an increased force for 10 s (for both axes) One-sample t-tests were used to test whether the mean differences between data obtained from the platform and given input was different than ' 0 '.

\section{Statistical Analyses}

Two-way within-subject design ANOVA's were implemented to examine the main and the interaction effects of height and slope. All variables except Ave_ $\mathrm{H}_{F}$ and $A v{ }_{-} \mathrm{V}_{F}$ were analysed with a sample size of six. Ave_ $\mathrm{H}_{F}$ and Ave_ $\mathrm{V}_{F}$ data were divided into five fractions to investigate the temporal changes in detail. For all tests, the alpha level was set at .05 significance level.

\section{RESULTS}

T-test results indicated that the mean differences for all loadings were not different than zero showing the accuracy of the platform is reliable for static and dynamic measurements ( $p>$.01)

Analyses showed no significant interaction effect. MT ( $p=.009)$, and BT

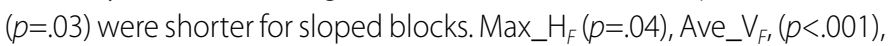
Max $\mathrm{V}_{F}(p<.001)$, and $\mathrm{V}_{J}(p=.001)$ were greater for sloped blocks (Figure 5). In a given sample data, it can be seen more resultant force vectors close to the vertical axis were observed in sloped blocks (Figure 4). Fractional analyses indicated that the block slope has a significant effect on the

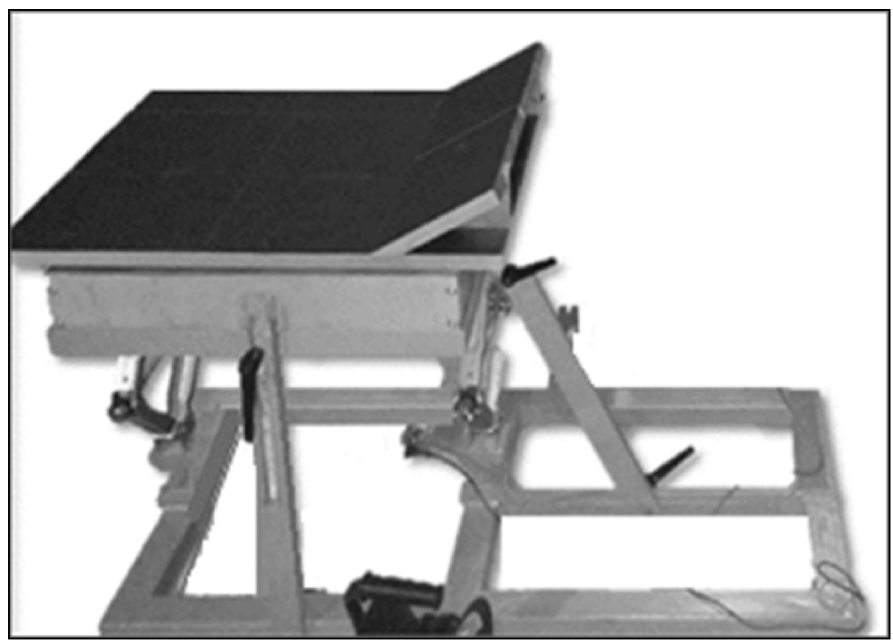

Figure 4. Replica of the OSB11 Starting Block. first fraction, and swimmers generated more $V_{F}$ in this fraction $(p<.01$; Table 2). The main effect of block height was found for $\mathrm{t}-5 \mathrm{~m}$ ( $p=.005)$.

\section{DISCUSSION}

\section{Block Height}

In our study, we found a significant effect of block height on the 0-5m time. Although pairwise comparisons did not show any significant difference, descriptive statistics demonstrated an increase for time to reach $5 \mathrm{~m}$ when swimmers dove from the lower $(.65 \mathrm{~m})$ blocks. After an extensive literature review, we could not find a study examining the relationship between block height and 0-5m performance. Nevertheless, explaining this result may be possible with the simple laws of physics. The higher blocks can provide a longer aerial travelling to swimmers, which result in a lesser water drag resistance for $0-5 \mathrm{~m}$, and decrease $0-5 \mathrm{~m}$ times. However, without measuring the flight distance or flight time, this explanation can be speculative only.

Gehlsen and Wingfield ${ }^{19}$ found increments for vertical and resultant velocities upon the water surface for pike and flat grab starts as starting blocks got higher. They didn't give any clear explanation for the velocity increments. Probably the vertical and resultant velocities increased as a result of gravitational forces acting on the swimmers' body mass as the height increased. The fact that platform height has no effect on horizontal velocity was a common finding with our study and theirs.

Cornett, White ${ }^{15}$ reported significantly faster head velocities at the maximum head depth for dives from the standard block $(.76 \mathrm{~m})$ and pool deck $(.21 \mathrm{~m})$ than dives from the intermediate block $(.46 \mathrm{~m})$. Unfortunately, they did not give a clear explanation for this non-linear relation and associated their results to the training background of swimmers. Besides, the velocity of the swimmers was measured under the water. Since variables such as drag resistance and lift forces are linked with the underwater velocity, it was not possible to compare their results with ours.

\section{Block Slope}

A significant effect of block slope was found for the movement time, which was approximately .05s faster for dives from the sloped blocks. Elliot and Sinclair ${ }^{16}$ indicated that block slope did not affect movement time when the grab start was used. Also Stewart ${ }^{18}$ stated that regarding power production 10 degrees slope was not advantageous for the grab start. On the other hand, grab start technique is most opposite technique to the kick-start in terms of feet positioning. It seems that unlike the grab start, where the two feet stand side by side, the kick-start technique is affected by the block slope.

Contrary to previous studies ${ }^{22-25}$ increase of centre of mass distance to the front edge did not increase the movement time in our study. Since these studies investigated the effect of different centre of mass positions using only fixed sloped blocks, there was no possibility to compare our results with theirs in terms of this variable. In our study, swimmers exerted a greater amount of force in both axes; consequently, they left the block quicker when sloped blocks were used.

Even though a significant increase found for maximum horizontal force, the effect of the slope on horizontal impulse and horizontal takeoff velocity was not substantial. There were two explanations for these results. First, for the sloped settings, the average horizontal force was not increased enough to make a difference between settings. Second, the movement time was longer for flat settings, that led an increase in horizontal impulse which was pointed out as one of the main predictors of horizontal take-off velocity in studies of Benjanuvatra, Edmunds, ${ }^{26}$, Slawson, Conway, ${ }^{5}$ Vantorre, Seifert. ${ }^{27}$ 


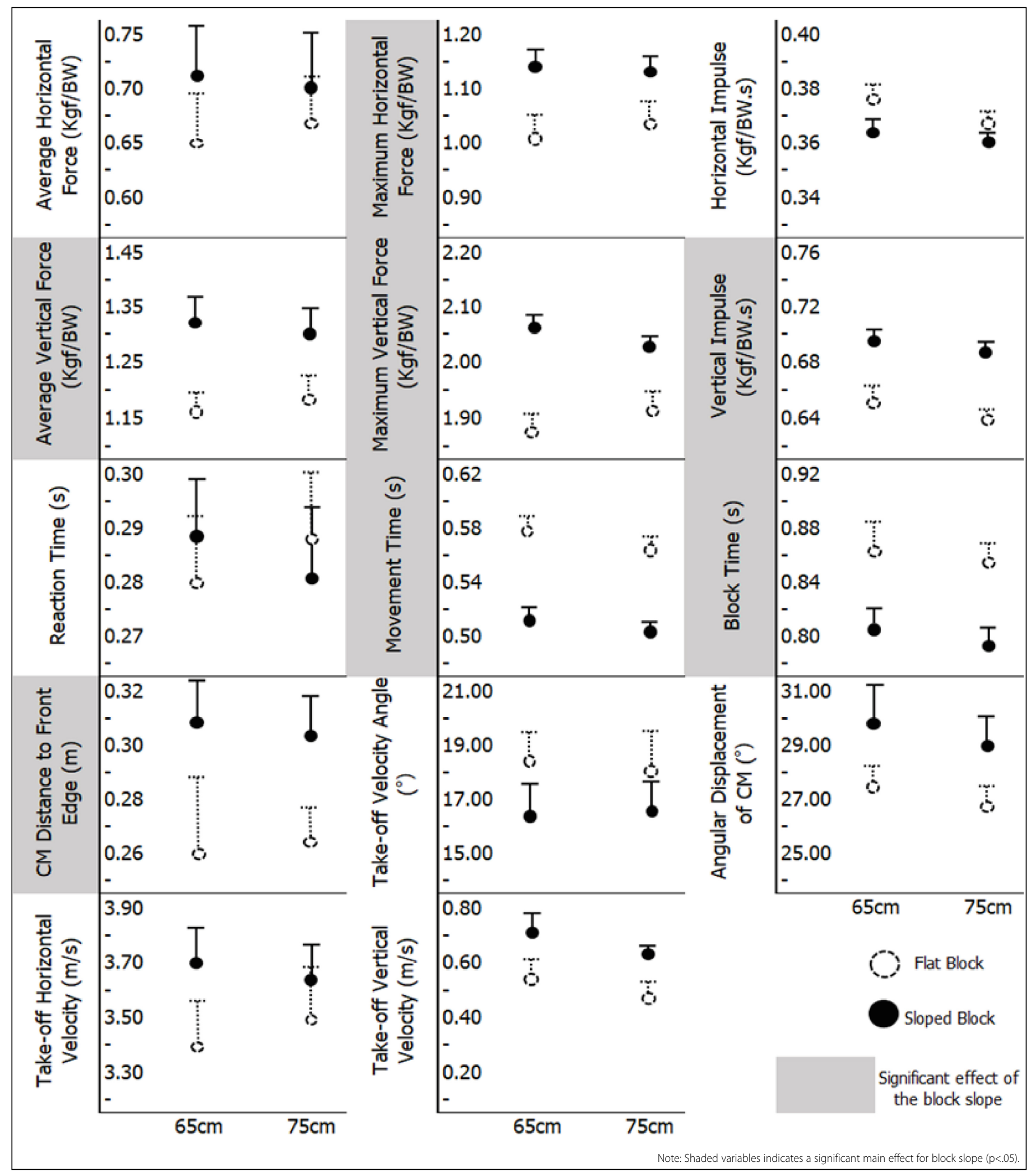

Figure 5. Effects of Block Height and Slope on Kinetic and Kinematic Variables.

Greater vertical force generation on block permits longer flight times, and it is an advantage if a swimmer can use this force to increase the flight distance. In our study, swimmers generated greater average and maximum vertical forces on sloped blocks. Correspondingly, the vertical impulse was greater even though the movement time was shorter for these block settings. The results thus show that the sloped blocks are favourable for swimmers regarding vertical force generation. Nonetheless, one point to consider has emerged with the results of the fractional analyses, which indicated that block slope was most effective at the first 20\% of the block phase regarding vertical force. As stated in the study of Sakai, Koike ${ }^{28}$ in this duration swimmers exert countervailing vertical forces with both hands and feet to induce pretension of muscles for increasing the torque at joints. Considering the position and role of the hands, the forces applied with the legs mostly provide this forward-downward movement. Since take-off horizontal and vertical velocities were higher, downward motion of CM does not necessarily indicate that the sloped blocks have adverse effects on start performance. Swimmers should be aware of this effect of the 


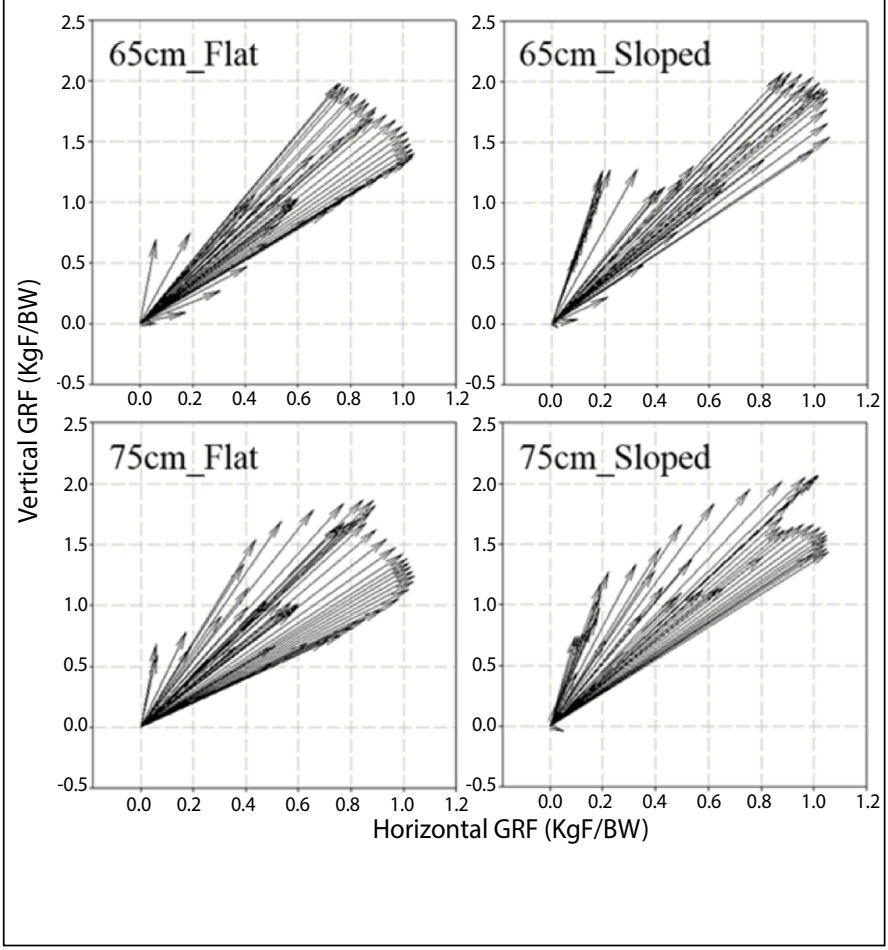

Figure 6. Participant 1's Resultant GRF Vectors for All Block Settings.
Table 2. Main Effects of Block Slope on Vertical Force in 5 Fractions of Block Time (KgF/BW).

\begin{tabular}{c|c|c|c|c|c|c|c|c|c|c}
\hline & & \multicolumn{2}{|c|}{$65 \mathbf{c m}$} & \multicolumn{6}{c|}{$65 \mathbf{c m}$ sloped } & \multicolumn{3}{|c|}{$\mathbf{7 5} \mathbf{c m}$} & \multicolumn{3}{|c|}{$\mathbf{c m}$ sloped } & \\
\hline Fraction & $\mathbf{n}$ & $\mathbf{M}$ & SD & $\mathbf{M}$ & SD & $\mathbf{M}$ & SD & $\mathbf{M}$ & SD & $\mathbf{p}$ \\
\hline $1^{\text {st }}$ & 6 & 0.87 & 0.08 & 0.99 & 0.04 & 0.88 & 0.11 & 1.01 & 0.04 & $.01^{*}$ \\
\hline $2^{\text {nd }}$ & 6 & 1.23 & 0.23 & 1.47 & 9 & 1.22 & 0.29 & 1.45 & 0.06 & 0.1 \\
\hline $3^{\text {rd }}$ & 6 & 1.63 & 0.21 & 1.8 & 0.15 & 1.62 & 0.17 & 1.75 & 0.11 & 0.14 \\
\hline $4^{\text {th }}$ & 6 & 1.35 & 0.09 & 1.64 & 0.16 & 1.41 & 0.28 & 1.62 & 0.19 & 0.51 \\
\hline $5^{\text {th }}$ & 6 & 0.77 & 0.1 & 0.85 & 0.19 & 0.83 & 0.2 & 0.88 & 16 & 0.63 \\
\hline
\end{tabular}

sloped blocks and try to generate well-distributed forces during block phase for increasing flight distance, and consider horizontal drive of the body. The intention of repositioning the CM regarding block slope was not clear. Swimmers might lean more forward on the flat blocks because they felt more balanced and safer.

\section{CONCLUSION}

Based on our results, blocks with $75 \mathrm{~cm}$ height and $10^{\circ}$ slope can provide favourable block performances to the swimmers. Coaches should know the effects of these blocks on start performance in terms of biomechanics and design their training regimens in accordance.

\section{ACKNOWLEDGMENTS}

This study supported by the Middle East Technical University Scientific Research Projects Department under the grant no BAP-05-04-2011-001.

All authors declare no potential conflict of interest related to this article

AUTHORS' CONTRIBUTIONS: Each author made significant individual contributions to this manuscript. UO: conceptualization, data curation, formal analysis, funding, acquisition, investigation, methodology, software, supervision, validation, visualization, writing - original draft, writing - review \& editing. FK: conceptualization, methodology, supervision, writing-review \& editing (supporting). SK: methodology, supervision, writing - original draft, writing - review \& editing (supporting).

\section{REFERENCES}

1. Galbraith H, Scurr J, Hencken C, Wood L, Graham-Smith P. Biomechanical comparison of the track start and the modified one-handed track start in competitive swimming: an intervention study. Journal of applied biomechanics. 2008;24(4):307-15.

2. Blanksby B, Nicholson L, Elliott B. Swimming: Biomechanical analysis of the grab, track and handle swimming starts: an intervention study. Sports Biomechanics. 2002;1(1):11-24.

3. Hay J, Guimaraes A, Grimston S. A quantitative look at swimming biomechanics. Swimming technique. 1983;20(2):11-7.

4. Ruschel C, Araujo LG, Pereira SM, Roesler H, editors. Kinematical analysis of the swimming start: block, flight and underwater phases. ISBS-Conference Proceedings Archive; 2007

5. Slawson SE, Conway PP, Cossor J, Chakravorti N, West AA. The categorisation of swimming start performance with reference to force generation on the main block and footrest components of the Omega OSB11 start blocks. Journal of sports sciences. 2013;31(5):468-78.

6. Thow JL, Naemi R, Sanders RH. Comparison of modes of feedback on glide performance in swimming. Journal of sports sciences. 2012;30(1):43-52

7. Vantorre J, Seifert L, Bideau B, Nicolas G, Fernandes R, Vilas-Boas J, et al. Influence of swimming start styles on biomechanics and angular momentum. Biomechanics and Medecine in Swimming XI, Oslo Nordbergtrykk. 2010:180-2.

8. OMEGA ${ }^{\bullet}$. OSB11 - SWIMMING STARTING BLOCK. 2016

9. Beretić I, Đurović M, Okičić T. Influence of the back plate on kinematical starting parameter changes in elite male serbian swimmers. Facta universitatis-series: Physical Education and Sport. 2012;10(2):135-40

10. Nomura T, TakedaT, Takagi $H$, editors. Influences of the back plate on competitive swimming starting motion in particular projection skill. XIth International Symposium for Biomechanics and Medicine in Swimming; 2010

11. Ozeki K, Sakurai S, Taguchi M, Takise S, editors. Kicking the back plate of the starting block improves start phase performance in competitive swimming. ISBS-Conference Proceedings Archive; 2012.

12. Takeda T, Takagi H, Tsubakimoto S. Effect of inclination and position of new swimming starting block's back plate on track-start performance. Sports Biomechanics. 2012;11(3):370-81.

13. Biel K, Fischer S, Kibele A, Kjendlie P, Stallman R, Cabri J. Kinematic analysis of take-off performance in elite swimmers: New OSB11 versus traditional starting block. Biomechanics and Medicine in Swimming XI. 2010.

14. Honda K, Sinclair P, Mason B, Pease D, editors. A biomechanical comparison of elite swimmers start performance using the traditional track start and the new kick start. XIth International Symposium for Biomechanics and Medicine in Swimming; 2010.
15. Cornett AC, White JC, Wright BV, Willmott AP, Stager JM. Block height influences the head depth of competitive racing starts. International Journal of Aquatic Research and Education. 2011;5(2):5.

16. Elliot GM, Sinclair H. The influence of the block angle on swimming sprint starts. First International Symposium on "Biomechanics and Swimming, Waterpolo and Diving", 14-16 September 1970 Proceedings. 1971:183-9.

17. Stevenson JR, Morehouse C. The influence of starting block angle on the grab start in competitive swimming: Pennsylvania State University; 1977.

18. Stewart V-L. Influence of block angle and diver stance on power production and takeoff velocity in swim starting: University of Ottawa (Canada); 1996.

19. Gehlsen G, Wingfield J. Biomechanical analysis of competitive swimming starts and spinal cord injuries. Journal of Swimming Research. 1998;13:23-30.

20. de Leva P. Adjustments to Zatsiorsky-Seluyanov's segment inertia parameters. Journal of biomechanics. 1996;29(9):1223-30

21. Taladriz S, de la Fuente-Caynzos B, Arellano R. Analysis of angular momentum effect on swimming kick-start performance. Journal of biomechanics. 2016;49(9):1789-93.

22. Barlow H, Halaki M, Stuelcken M, Greene A, Sinclair PJ. The effect of different kick start positions on OMEGA OSB11 blocks on free swimming time to $15 \mathrm{~m}$ in developmental level swimmers. Human movement science. 2014;34:178-86.

23. Honda K, Sinclair P, Mason B, Pease D, editors. The effect of starting position on elite swim start performance using an angled kick plate. ISBS-Conference Proceedings Archive; 2012.

24. Vilas-Boas JP, Cruz J, Sousa F, Conceicao F, Fernandes R, Carvalho J, editors. Biomechanical analysis of ventral swimming starts: comparison of the grab start with two track-start techniques. IXth World Symposium on Biomechanics and Medicine in Swimming Saint Etienne: University of Saint Etienne; 2003.

25. Welcher RL, Hinrichs RN, George TR. Front-or rear-weighted track start or grab start: Which is the best for female swimmers? Sports biomechanics. 2008;7(1):100-13.

26. Benjanuvatra N, Edmunds K, Blanksby B. Jumping abilities and swimming grab-start performances in elite and recreational swimmers. International Journal of Aquatic Research and Education. 2007;1(3):6.

27. Vantorre J, Seifert L, Vilas-Boas JP, Fernandes R, Bideau B, Nicolas G, et al., editors. Biomechanical analysis of starting preference for expert swimmers. ISBS-Conference Proceedings Archive; 2011.

28. Sakai S, Koike S, Takeda T, Takagi H, editors. KINETIC ANALYSIS OF START MOTION ON STARTING BLOCK IN COMPETITIVE SWIMMING. ISBS-Conference Proceedings Archive; 2016 